\title{
Microwave Radiometry in Remote Sensing
}

\section{Gudmandsen, Preben}

\section{Published in:}

12th European Microwave Conference

Link to article, DOI:

10.1109/EUMA.1982.333135

Publication date:

1982

\section{Document Version}

Publisher's PDF, also known as Version of record

Link back to DTU Orbit

\section{Citation (APA):}

Gudmandsen, P. (1982). Microwave Radiometry in Remote Sensing. In 12th European Microwave Conference (pp. 3-4). IEEE. https://doi.org/10.1109/EUMA.1982.333135

\section{General rights}

Copyright and moral rights for the publications made accessible in the public portal are retained by the authors and/or other copyright owners and it is a condition of accessing publications that users recognise and abide by the legal requirements associated with these rights.

- Users may download and print one copy of any publication from the public portal for the purpose of private study or research.

- You may not further distribute the material or use it for any profit-making activity or commercial gain

- You may freely distribute the URL identifying the publication in the public portal

If you believe that this document breaches copyright please contact us providing details, and we will remove access to the work immediately and investigate your claim. 
P. Gudmandsen *

\section{ABSTRACT}

Microwave radiometry has shown its capabilities of observing and monitoring large-scale geophysical observables from space. Examples are sea surface temperature and surface wind over the ocean, sea ice extent, concentration and category and snow cover extent and water content. At low microwave frequencies the atmosphere is virtually transparent even with clouds which make microwave radiometry very valuable in regions with frequent cloud cover such as the temperate and arctic zones. At high frequencies, however, atmospheric absorption will degrade measurements of earth surfaces but this phenomenon proves useful for measurement of atmospheric parameters. Examples are detection of rain cells and frontal systems, temperature and humidity profiles and content of minor constituents in the atmosphere foremost above the troposphere.

The above examples have been demonstrated from radiometer measurements from balloon, aircraft and spacecraft and it is expected that the next generation of spacecraft may encompass microwave radiometers in the frequency range from perhaps $1.4 \mathrm{GHz}$ to $700 \mathrm{GHz}$ taking advantage of a number of new developments. With the purpose of identifying the necessary developments an international workshop was organized in June 1982 with the object of reviewing the state-of-the-art in applications and techniques and to suggest future development work in data processing and application, systems principles and performance and in component development including the antenna system.

The presentation to be given will review the findings of the workshop but in brief it can be stated that future development in radiometry is likely to concentrate on improving the present technique at frequencies below $40 \mathrm{GHz}$ for ocean and ice/snow applications perhaps supplemented by radiometers in the atmospheric windows at $90 \mathrm{GHz}, 140 \mathrm{GHz}$ and $200 \mathrm{GHz}$. The aims will mainly be directed towards improving the spatial resolution and to solve the problem of spatial resolution versus sensitivity (radiometric resolution). It is felt that operational systems may be realized in the next decade.

This may also apply to techniques towards measurement of meteorological phenomena as wind, rain and frontal systems and atmospheric profiles of temperature and humidity. However, measurement of the minor constituents in the atmosphere based on observation of absorption lines by means of microwave spectrometers is still in its research phase to answer questions like: What constituents can be observed and to what extent is it possible to monitor spatial, daily, seasonal and yearly variations. Spectrometers at millimeter and submillimeter wavelength shall be developed for spaceborne use for the limb sounding technique where the

* Electromagnetics Institute, Technical University of Denmark, Lyngby, Denmark 
antenna beam scans the atmosphere from $10 \mathrm{~km}$ to about $120 \mathrm{~km}$ above the ground. A great deal of the development will concentrate on quasioptical systems (even at low frequencies) drawing upon developments in radio astronomy. An interesting problem is that of developing a space qualified local oscillator at frequencies above $400 \mathrm{GHz}$.

The workshop was organized as a part of a contract with European Space Technology Centre, Noordwijk, the Netherlands. 